\title{
formas eólicas
}

Greda, grés, saibro, brita, cré, silicosos, calcáreos, quartzíticos, ferruginosos, vulcânicos, herméticos:

areal de vento, impalpável, nascente, migrante, perolado, areal de osso, areal de chumbo - uns, impiedosamente macios, tiram a resvalar declive abaixo sons característicos de si, agudos ou graves: "areias sonoras" ou um zumbir que leva minutos; outros, obscurecem o céu.

Ao fim da decomposição, "formas eólicas": vagando sem descanso, dunas lineares, dunas transversais, em cristas, valados, corpos de dunas, ancas de dunas, em forma de ovo, crescente, coração, ferradura, Passarges, barcanas, que sepultam sob si tudo o que vive.

Arte pura que dispensa artistas, movida por movimento incessante, nova e improlífica, desenho puro que ninguém vê, que se desenha em si mesmo, belo, deserto, distração para os deuses. 